\title{
第2回根研究会シンボジウム一植物根系の理想型一
}

名古屋大学農学部

山内 章

標記シンポジウムを 5 月 21 日〜 2 2 日の 2 日間にわたって、唐津市近代図書館を会場に開催した。 実はこのテーマでのシンボジウムの開催は一部の会員の間でかなり以前から希望が出されていた。植 物を個体あるいは集団レベルで研究する際、その植物の成長、繁殖、生産（収量）等を支える最適な 根系とはどのようなものであるか、という問いかけは根系研究者のとってはライフワーク的テーマで ある。具体的には第 1 回シンボジウムにおいて、高橋秀幸氏（東北大学遺伝生態研究センター）から、

「なぜ、根（系）を研究するのか」と問いかけられたことが本シンボジウムを組織する出発点になっ たと記憶している。

当初、シンポジウムを計画したときには、どの程度のものができるかたいへん心許ない状態であっ たか、結局佐賀大学農学部、同海浜台地生物生産研究センターに主催に加わっていただき、さらに唐 津市から後援をいたたいて、財政的にも、運営面でも絶大なこ支援をいただき、当初予想もしなかっ たほどのたいへん充実したシンボジウムとなった。この場を借り関係者の皆様に改めて心から感謝を 申し上げる。

シンボジウムには、文字どおり北は北海道、南は沖縄まで 119 名もの多数の方が参加して下さり、 その内訳は大学、国公立試験場・研究所等出身の研究者、普及員、企業・報道関係者、学生など多岐 にわたり、この課題に対する関心の強さを伺わせた。

シンボジウムの主旨については、前号 (第3巻第 1 号) で述べたのでここでは繰り返さない。今回 の講演者は、これまでそれそれの分野で目さましい成果を挙げてこられた方ばかりであり、本シンポ ジウムは根系研究における現在までの到達点を示しえたと考える。詳しい講演内容については、本号 の講演要旨を参照していただこととして、簡単にそれそれのお話を振り返ってみる。

まず、秋田氏には、根の研究者が根の「理想型」を考えていく上で大いに学ぶべき点があると考え、 理想的草型の概念の確立された過程と、それを基にした様々な分野からの学際的基礎研究の積み上げ の結果、最終的に高収量品種の開発として実を結んだ経緯についてお話をいただいた。根の研究に対 する批判的な見解もこ披露いたたいた。これを受けて、田中氏には茎葉部との共通点、根独自の問題 を整理し、作物の理想的根系についてのお考えをこ披露いただたたここまでの議論では、念頭にあ る植物は草本で、基本的視点は「生産」にある。次に、山下氏には同じ作物であるか、木本植物であ る果樹の根系の理想型について議論していたたいた。また、果樹は上の二つのこ講演の内容と、次の 荻住氏の樹木の根系の話との橋渡し的な位置つけにもなった。「理想型」の追求 (科学) が、技術的 な展開を目指すとすれば、果樹の分野はその実現に向けて最も近いところまできているという感を強 く持った。茠住氏には、林学の立場から、生産・管理と、自然生態系における植物という2つの視点 で、樹木の理想的根系についての議論を展開していたたいた。先生の話は、森林生態系・環境の保全、 都市の緑化、文化財の保護（樹木の中にもある）にとっても大いに示唆に富んだものであった。可知 氏は、自然生態系における植物の理想的根系について、生産という立場を離れ、個体の成長の最適化 という面からの議論を分かりやすく展開された。先生が用いておられるシミュレーションの手法は、 今後の根系理想型研究にとって、たいへん有効な手段であると考えられた。最後に河野氏には、土壤 という、茎葉部とは全く異質な生育環境が植物の理想的根系を考えるときの決定的に重要な要因であ ると考えられるので、その点について植物一土壇相互関係を中心にお話いただいた。第一次生産者で ある植物根を中心とした土壤生態系の見方に重点を置き、今後の環境保全型農業に向けての栽培技術 の体系化の中で根の果たす役割についてまで言及していただいた。

これらの講演に関して参加者を含めての議論も活発に行なわれ、このてのシンポジウムとしては議 論がたいへんよくかみ合い、中身の濃いものになった。

このシンボジウムの成果は、その内容の重要さを考えたとき、当初の目標にあった通り、世に公に して批判を仰ぐ価値がじゅう分にあると考えられるので、可能なら討議の内容も踏まえた形で、出版 (日本語と英語) の計画が進んでいる。このシンポジウムを契機として、研究会内でも根の「理想 型」についての議論が巻起ることを期待したい。 


\section{作物の多収性と草型をめぐって 秋田重誠}

作物收量の決定過程は、生態的要因、さらには個体群の構成単位である作物個体の生理 形態的（morpho-physiological）諸要因など多要因の影響を受ける。なかでも、形態的形 質は、人閒の視覚で捉えられる形質であり、栽培管理、育種に当たって改良の対象として 好都合であるうえ、生理生態的形質とも、しばしば、強い関連性を持つため多収性研究の 対象として取り上げられ、草型理論などが展開されてきた。そこで、ここでは作物あるい は作物個体群の形態的諸要因を主たる対象とし、多収性との関連性について概観する。

耕地生態系下における太陽エネルギーの固定は植被（canopy）により行われるが、植被 もエネルギー固定系としては個葉と相同であり、そのエネルギー固定量は個葉における光 エネルギー固定が色素の種類、量、エネルギー変換効率のような生理的形質とともに、葉 緑体の配列の仕方、量により影響を受けるのと同様に、植被を構成する個葉の量、角度な どの形態的諸形質により変化する。また、光エネルギー固定系の形態は、光強度に応して 変化し、陰萧、陽葉、陰性植物、陽性植物など光環境に応じた多様な適応型が見られる。 このように形態的諸特性と光合成効率が光環境により変化する根源は光合成系の基本単位 である菄緑体の光一光合成関係が值線ではなく、飽和型の双曲線により近似される特性を 持つことによる。光一光合成関係が直線であれば形態的形質の関与の余地ははるかに小さ いものであったと考えられよう。植被がエネルギー固定系として見た場合、個葉と異なる 点は同化器官に対する非同化器官の量が一般的に大きくなること、さらには、エネルギー の担体である炭素および空素化合物などの合成に必要な無機塩類および水を根を通して植 被に吸収し、そこで種々の生合成を行なうことであろう。このような根の存在も植被とい う作物の光エネルギー固定系固有の問題であり、根の形態的諸形質が栄養塩類、水の吸収、 地面への固着程度（倒伏程度への影響）など、植被全体のエネルギー固定過程に影響を及 ぼし、ひいては多収性に関与する。この植被により固定されたエネルギーから光合成工場 である植被自身の維持のためのエネルギー消費がなされ、余剩のエネルギーが植被自身を 構成する種々の物質の生合成および貯蔵にむけられるため、維持エネルギー量、光合成、 非光合成系へのエネルギー分配、さらには収量部分に関与する形態的諸形質が収量と密接 な関連性を持つ。

\section{多収と理想型草型}

光エネルギーの吸収、固定に関係する植被、固定したエネルギーの分配に関与する形態 的諸形質と多收性との関連性については、理想型草型(ideotype)が提唱され、単一の "ideotype"が多収のための万能であるかのごとき誤解を抱かれた時代むあった。しかし、 現在では、多収のための"plant type"は普遍的な単一のものではなく、自然的環境、人為的 制御程度など栽培環境に応じた"ideotype"が存在すると理解されている。自然条件のよう に人為的制御がほとんどなされない条件下での作物栽培における収量性、すなわち、例え ば除草剤、肥料が無い条件下では、雑草との競合に打ち勝つための”高さ”を獲得するこ とが必要となり、茎や桿部分へのエネルギー分配を增大することが生存に不可欠となる。 
したがって、茥部分へのエネルギー分配低下は収量性の大きな低下をともない、伝統的な 草丈の高い品種がそのような条件下での多収品種となる。このように多収のための草型は 基本的には作物の栽培のための人為的制御の程度により異なる。また、"ideotype"は往々 にして栽培環境ごとに単一の生態型として描かれる場合が多いが、本来、生育時期ごと "ideotype"は動的に変化するものでもある。より正確には、"V字理論”など多収のため の分施技術にみられるように収量部分の形成時期にエネルギ一固定量を最大化するために、 各々の生有時期ごとに異なった"ideotype"が存在すると考えるべきである。

かっては、一般に根の生育量の增大は多收をもたらすと考えられ、根研究は多収研究の 主流であった。現在でも、しばしば、根への物質分配の大きさと収量性の間に正の相関が 見られ、明らかに根の発達を促し、水分、美分の利用可能領域を拡大することが多収の鉄 則となる場合がある。しかし、これは畑作、不良土壌のように人為的制御が困難な耕地生 態系下での作物においてであり、現在の水稲や野菜の栽培のように栽培環境の人為的制御 が可能な耕地生態下あるいは施設での生産においては、不都合が生しない限り根、茎など 非同化器官へのエネルギーの分配を低下させる半矮性などの形態的特性が多収の基本原理 となっている。かっての「根梁くして草繁る」は現在では普遍性を持っとは言い難い。

\section{多収化に向けた形態的諸形質の最適制御}

多収のためには根などへの物質分配が減少させる方向の技術が有効であると述べたが、 現在でも根への物質分配の減少は環境変動に対する安定性を明らかに低下させ、多収性は 環境変動による収量の変動の増大をともないやすい。一方、畑作物の多収には現在でも根 が最重要形質であると述べたが、畑作物といえども、水分ストレスが小さく、美分的にも 問題がない場合には根への物質分配の減少が多収をもたらす事例は見られる。したがって、 作物の多収化にあたってはストレスの種類、程度に応じて草型は決定されるべきである。 さらには、根の生理的活性の指標となる溢液量は地上部の光合成による呼吸基質供給量に 支配されるのであり、植物ホルモンの器官間の移行など器官間のエネルギー分配には強い 相互作用が存在する。したがって、収量最大化のための各器官への最適エネルギー分配量 は、このような器官間のエネルギー分配、これに関連する諸形質の最適制御が不可欠とな る。収量を最大化するための各器官へのエネルギー分配の最適化こそ栽培管理の要諦でも あり、栽培研究者としての立場をとるならば根だけを研究の対象とするわけには行かない。 このような、多要因間の相互作用などの複雑な解析、篤農家の技術のような普遍性を欠く 技術の内容の解析などに対し、シミュレーション手法の有用性が高いことが実証され、今 や栽培研究の主要な手法となりつつある。

今後とも、作物をとりまく栽培環境は作物の種類、栽培地域、社会経済的状況により変化 する。このような状況の変化は栽培環境の制御程度の違いをともなうが、農業においては このような状況下でつねに収量性を最大化することが求められる。昨今、有機農法など農 業生産の持続的発展に対応した栽培技術開発の必要性も咱えられており、このような状況 に対応するためにも、これまでの化学肥料など補助エネルギー依存型農業から作物自身の 生産性の向上、環境耐性の一層の向上をめざした新しい"plant type"が求められよう。 


\section{作物における理想的根系（序説） \\ 田中典幸}

\section{1.はじめに}

根は中期古生代における陸上植物の進化にともなって、環境に適合しながら茎葉部の支 持と養水分吸収を主な機能として、形態的にも機能的にも高度な分化を遂げてきた器官で ある。しかし、地上部が茎、茟、花（生殖器官）と分化したのに対して、根にはこのよう な異質的な分化は見られない。地下部の生育環境は地上部に比べて変化にそしいとされる が、根は局在的不均一性の大きい環境で生育する。根には、地中根、地上根のほか水中根 などの多様な分化がみられる。本稿では地中根について述べるが、双子葉作物に見られる main root systemや単子葉植物のfibrous root systemの二つの根系が中心をなしている。

\section{2. 理想的根系を求めて-その手法的展開}

1）孤立個体における生育秩序の解明：片山は、稲・麦の生長が極めて几帳面 で、しかも単純な秩序によって統一されていることを見いだし、同伸茟・同伸分げつの理 論を確立した。そして、この秩序が破れたならば収量の低下は免れないとした。すなわち、 抑制要因を限りなく取り除いた環境で生育する孤立個体の規則的で完璧な生育パターンを 理想型とし、これを生産の場（個体群落）に移して理想的生育からの”ずれ”または”久 落”に着目して生育・収量診断を行う手法である。この思潮はイネ科作物の根系の研究 （藤井・田中）にも引き継がれ、葉の出現・展開を基調にした規則的な根系の生育秩序を 解明し、理想的根系の生育パターンとして提示した。川田グループは水稲の提起する生態 的諸問題を解明する手法として形態形成論 (morphogenesis) の立場から、phyton theory を基調として、根系の示す多様な形状の由来を追求した。研究の領域は孤立個体から個体 群落と広範に及び、根系の存在する環境要因と根の生育、形状、機能の変動を解明する中 で理想的根系を追求していく手法が同われる。一方、筆者はマメ科作物（16種）の根系を 対象としてこれらの生育パターンの解明を進めたが、イネ科作物とは根系形成の図式も様 式も異なり、無秩序と見える根群の発育習性に3つのパターンを見出した。これらのパター ンは遗伝的なものであるが、マメ科にみられる根形成帯（部位）の非限定的分布のほか二 次生長（肥大生長）によって形成される異径根群（根系を構成している個々の根の直径が 著しく異なるもの。イネ科では構成根の直径が近似しており等径根群と呼ぶ）では太さの 異なる根が伸長、分枝および肥大成長してパターンからしばしば外れた複雑な生育をする ことから、孤立個体や群落生態における総根長（または全表面積）、最高分枝、根系の分 布領域などの調査を行い、これらの結果を絵合して理想的根系の形態や機能を想定するこ とは難しい。なお、異径根群の場合は環境要因によって根の生育に比較的大きな変化を示 すことも原因である。したがって、異径根群の構造解析の手法として、筆者らは樹木の茥 苯部を対象として、吉良によって掲示されたパイプモデル理論を適用し、これを更に発展 させることを考えた。

2）根系モデルからみた理想的根系：茎・根に二次肥大がみられるマメ科草本 は茎または根の断面積に占める通導断面積の割合が高く、パイプモデル理論への適応性が 高いと考えられた。筆者らは、大豆を供試してパイプモデルを適用して、根系の量を或る 
程度まで推定しうることを明らかにしたが、さらに、根系モデル（仮想パイプモデル）に よる構造の解析を行い、根系構造の直径階級別分級を基に根系構造の総合的な把握を行っ ている。根系がパイプモデルに完全に当てはまるならば、各直径階級の根系モデルは円筒 形となる筈である。しかし実際の根系では生育条件にかかわらず直径が約 $1 \mathrm{~m} \mathrm{~m}$ 未满の細根 ではパイプモデルに適合しない部分が存在する。この非適合部分は美水分の吸収やホルモ ン合成など生理機能の高い部分で、地上部の葉（同化部分）に相当すると想定している。 多くの場合、非適合部分の占める根表面積の割合は極めて大きいばかりでなく、根の表面 積と葉面積との間に高い有意な正の相関関係が認められる。両者の比は生育環境によって 変化する。たとえば、土壌締め固め区より有機物施用区においてはるかに大きく、また、 乾燥と湿潤土壌では前者で大きい。すなわち、根系モデルによる根系構造の解析は根系を 構成するすべての根を短材に切断し、その構成内容を踏まえて根系構造を詳細に解析する ことが可能となるので、理想的根系を追求する上での極めて有効な手法になり得ると考え られる。

3）Shoot-Rootの相対生長からのアプローチ： 環境要因に対して示す茎葉 部の多様な反応を理解するためには、根も葉も一体のものとして捉える必要がある。この ような視点から、Shoot-Rootの量的バランスの把握が行なわれた。栄養生長期にみられる 対数直線関係や、植物による違い、多収化にともなって根重の割合が減少する傾向も指摘 されている。一方、牧草の刈り取り後の再生時に本来のShoot/Root比へ復元する現象は Shoot-Root間の物質の分配を支配する生長調節物質の作用に求められなければならない。

\section{Shoot-Rootの生長調節機構}

1）ホルモン的制御： 茥葉部と根の相互関係は複雑なホルモン的制御システムによっ て調整されている（不明な部分も多いが）。不良土壤条件下における植物の生長、根の届 地反応、乾燥や湿潤に対する根の反応などもホルモンの関与において説明される。一方、 乾物の分配についてはsource-sinkの関係によって説明される場合もある。

2）環境要因： 光強度、養分、温度、土㭛理化学性、水分、通気、有機物、微生物、 種・品種、耕種法等々は茎萧部と根の乾物分配に影響するばかりでなく、環境の変化に対 するこれら器官の複雑な相互依存や菱萧部と根のバランスを微妙に制御している。

\section{4. おわりに}

理想とは「観念において、一切の現実的不備と欠陥とを捨象し、願わしい条件をことご とく具備させた状態」である（広辞苑）。根は遺伝と環境の産物であり、生産の向上につ ながる作物（根系を含む）の遺伝的解明と育種、より好適な生育環境の解明と具体化によっ て、作物の理想的根系像がより明確になると思われる。 


\section{樹木の根系（根量と吸収構造）}

茫住 昇

樹木の根系に関する研究には M.Bugen (1905) や J.E.Weaver (1920) の根系図に代表されるような 根系の形態と分布と土境環境や種の遗伝性に関する研究と根量から量的に解析研究する方法がある。 後者は、前者よりも根量調査に多大の労力を要することから大径木については研究が殆どない。

1960年頃から森林生態学や造林学の分野において森林の生産構造に関する研究が盛んになり、特 に地上部の Biomass の測定による生産構造の解析・研究が進んだ。しかし、地下部については調查 に多大のエネルギーを要することや、調査法が確立しないこともあって量的解析による研究はあま り進んでいなかった。1958年に筆者はソイル・ブロック・サンプリングによる根量調査法を考え、 この方法によって多数の樹種の根量調查を行った。ここでは根量測定による根系の機構と機能につ いてアウトラインを紹介する（図ー1）。

根量測定法：地下部における根の分布構造や働きを解析するためには根系区分（表一1）ごとの 根量を測定する必要がある。森林や樹木の根量を推定することは極めて困難であるが、ソイル・ブ ロック・サンプリング法を用いると比較的容易に根量を推定することができる。林内では根系分布 に個体間の交錯があるので、単木の根量を推定することは極めて難しい。いまブロックの面積を 1 本当り面積としてその根量と緻密に調査した単木当りの根量を比較すると両者の差は細根・小径根 では大で、大径根では小であった。

これらのことから根量は胸高断面積（または $\mathrm{D}^{2} \mathrm{H}$ 、材積）との相関が大で、調查木を直径階で大・ 中・小径木の階層に区分して、大・小径階から 3 本、中径階から 2 本、計 8 本の根量を測定すると 平均值が誤差率10\%、危険率10\%の籁囲内で推定できることがわかった（図一2）。

比推定法による根系区分ごとの根量の測定：根系区分ごとの根量の測定には比推定法 が用いられた。細根(f) ・小径根 $(\mathrm{s}) \cdot$ 中径根 $(\mathrm{m})$ の中でのmの推定（誤差率10\%、危険率10\%）には、 $\mathrm{f} \cdot \mathrm{s} \cdot \mathrm{m}$ の資料600 $\mathrm{g}$ 以上取ればよく、 $\mathrm{s} \cdot \mathrm{f}$ の推定には資料から $200 \mathrm{~g}$ 以上あればよいことがわかった。 また、単木の根量の推定には胸高断面積比による 1 本当り面積の根量を測定すればほぼ単木の根量 に近いものを推定できることがわかった。

根量・根系表面積など根系因子の推定：根系区分ごとの根量が測定され、各区分ごとの 平均の直径や容積密度数などがわかると、これから根系体積、根長、根系表面積など根に関する諸 因子を推定することができる。

根量：根量など各因子は木の胸高断面積と高い相関関係があるので直径よりも胸高断面積を $\mathrm{y}$ 軸 にとり、 $\mathrm{x}$ 軸に根系因子をとると理解しやすい。単木の場合、胸高断面積に対する細根量の変化は


ツ0.1kgとなった。根系の全量では放物線と反対の凹型の曲線となり、ヒノキ $60 \mathrm{~kg}$ 、アカマツ・カラ マツ $50 \mathrm{~kg} 、$ 、ズ $45 \mathrm{~kg}$ となった。ha当たり根量は本数に関係するので、細根は幼令木で大で、大径木 では小さくなった。全量では放物線状となる。

木の全量に刘する根量の割合：細根量の割合は幼令木で大で、大径木で小さくなる。特大 根・根株では放物線状に変化する。木の全重量に対する地下部量の割合は小径木から大径木まで変 化せず25\%程度であった。

根系の体積 : 根系の体積は根量とその容積密度数から計算することができる。スギの胸高断面積 $439 \mathrm{~cm}^{2}$ の単木の根系体積は $0.13 \mathrm{~m}^{3}$ であった。根量と根系体積分布の閒にはかなり大きな差がある。 細根は量では小さいが体積では大きな值となる。

根の長さ：各根系区分の直径、容積密度数根量の各土境層における分布は樹種によって異なるが 
I・II層（I：深さ 0〜15cm、II : 15〜30 cm）に70〜 90\%が分布した。細根の分布は表層で大きく、 染くなるにしたがって急速に減少することなどから、根長を推定することができる。スギの胸高断 面積 $439 \mathrm{~cm}^{2}$ の根長は $4.1 \mathrm{~km}$ であった。アカマツ $\left(361 \mathrm{~cm}^{2}\right)$ は、 $1.2 \mathrm{~km}$ で小さい。これは細根量の多宾

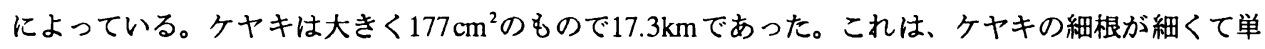
位当りの長さが長いことによっている。ha当りではスギ幼令林で $10,000 \mathrm{~km}$ 、平均胸高断面積400 $500 \mathrm{~cm}^{2}$ の林分で $3,500 \mathrm{~km}$ であった。幼令林でカラマツ $2,000 \mathrm{~km} 、 ア カ マ ツ 5,000 \mathrm{~km} 、$ ヒノキ $6,000 \mathrm{~km}$ 、 スギ10,000kmの順となった。

根系表面積：根の直径、容積密度数などから根系表面積を計算することができる。単木の全根系

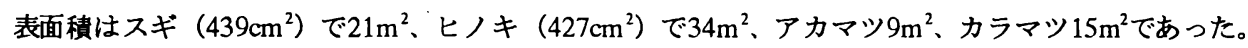
ha当り根系表面積はスギは $1.5 \mathrm{ha} 、$ ヒノキ2.5ha、アカマツ0.5ha、カラマツ1.0haとなる。根系表面積 の中で細根が占める割合はスギでは約 $60 \%$ 、小径根は $16 \%$ 、中径根 $9 \%$ 、その他 $15 \%$ あ゙った。根系 表面積の中で、細根・小径根が占める割合は大きい。

吸収構造：根系表面積の水平・垂直的な分布は樹木の養・水分の吸収と密接に関係している。根 系表面積は樹木の吸収構造を示すものと考えられる。胸高断面積 $439 \mathrm{~cm}^{2}$ のスギではI層に根系表面積

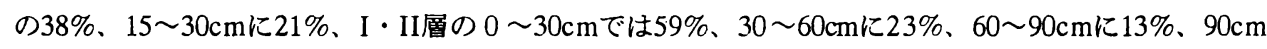


布した。I・II層では69\%となる。深根性のアカマツは57\%であった。樹木の吸收構造は水平的にも 考えられる。吸収構造は樹種、立地条件によっても変化する。

根系の最大深さ：根系の最大梁さは土㭛条件によって異なるが、一般森林土境では胸高断面積 $500 \mathrm{~cm}^{2}$ の樹木でスギは $2.2 \mathrm{~m}$ 、ヒノキ $1.5 \mathrm{~m}$ 、アカマツ $3.5 \mathrm{~m}$ 、カラマツ $2.0 \mathrm{~m}$ と推定された。

根密度 : ブロック法による根量の測定では根量が測定された面積や体積が異なるので、根量をそ のまま比較することはできない。この場合、根密度の考え方はきわめて有効である。根密度は土壌 $1 \mathrm{~m}^{3}$ 当たり根量 $\left(\mathrm{g} / \mathrm{m}^{3}\right)$ として表される。吸収作用に最も大きく関係するのは細根の根密度である。

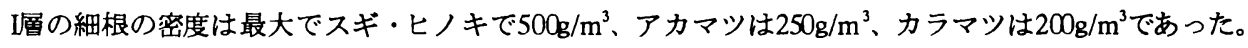
細根の根密度が最大になるのは幼令林で、中・高木材になると根密度は減少する。中・高全林では スギ $200 \mathrm{~g} / \mathrm{m}^{3} 、 ヒ ノ キ 400 \mathrm{~g} / \mathrm{m}^{3} 、 ア カ マ ツ 50 \mathrm{~g} / \mathrm{m}^{3}$ 、カラマツ $200 \mathrm{~g} / \mathrm{m}^{3}$ 程度であった。葉量と同様に一定 林分では根密度が一定の值をとる。根密度は林分の本数密度、土裹条件などによって変化する。根 密度からは根量を推定することができる。水平的には、一般に根株に近いところで大きく、杖ら 距離が離れるにしたがって綬曲線で減少する。根密度の垂直・水平分布などの変化は Gram-Charier 展開式があてはめがよい。根量、根長、根系表面積などがわかると、これらの因子当りの吸収量、 生産量などが計算できる。これを根系吸収率、根系生産率と言う。


$235 \mathrm{~g} / \mathrm{g}$ 、カラマツは $42 \mathrm{~g} / \mathrm{g}$ 。

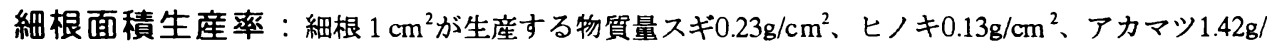
$\mathrm{cm}^{2} 、$ などとなる。その他全根系表面積生産率など計算することができる。樹木の大きさによる全根 系表面積生産率はほぼ一定であった。

根系吸水率：吸水に関する根系諸因子 $\mathrm{g}$ 当り吸水量cc゙表される。細根量吸水率はアカマツ 22.0


$\mathrm{cm}^{2}$ 、カラマツ $40 \mathrm{cc} / \mathrm{cm}^{2} 、 ヒ ノ キ 30 \mathrm{cc} / \mathrm{cm}^{2} 、 ア カ マ ツ 240 \mathrm{cc} / \mathrm{cm}^{2}$ に達した。

ソイル・ブロック・サンプリング法による一定積度での根量推定とこれに関する根系諸因子の測 定によって根系に関する各種の解析ができる。筆者はこの方法によって 802 本の根量調查を行った。 


\section{果樹における理想的根系}

\section{山下研介}

「果樹における理想的根系とは?」この命題の答をしいて求めようとすれば、それは 対象果樹に最高の収量と品質をもたらす根系ということになろう。そのような根系がはた してあるものかどうか、ここでは形と機能の両面から考えてみたい。

\section{1. 地上部と地下部の相互作用}

果樹が他の作物と異なっている点は、枝変わり、偶発実生、交雑育種で得られた優良品 種を根系としての台木に接木し、永年生作物として栽培する点にある。すなわち、地上部 と地下部は良好な共生関係にあることが肝要で、その相互作用について知見を加えること は、ここで与えられた命題を解く近道ということになる。最近のレビュウによると、地下 部から地上部に送られるシグナルにはpositiveなむのとnegativeなむのがあり、chemical なものとphysicalなものに分けられるとのことである。

ここで地下部つまり台木の特性について考えてみると、まず第一に遭伝的に均一であり、 わい化、耐寒性、耐病性、耐虫性、耐干性、耐湿性、耐塩性等に優れていることが望まし い。また、複雑な土墥環境に対して適応性を持つことも重要である。しかしながら、接木 には手間とコストがかかり、台勝ち、台負けなど栽培上の問題点もあるので、接穂品種そ のものが自根形成力を有し、しかも上述の諸形質を有していればこれに越したことはない。 リンゴのわい性台木のメッカであるイーストモーリング試験場では、この方向で研究が進 められているが、バイオの技術がいかに進んだとはいえ、現時点では、これは 21 世紀の 夢として、いましばらく待たねばなるまい。

\section{2. 樹形に刘応した根形というものがありうるのか?}

前述したように、優良品種はこれと接木親和性を示す台木に接木し、整枝せん定を行っ て一定の樹形に仕立てられている。盃状型、開心自然形、変則主幹形、スピンドルブッ シュ、棚仕立てなどがそれであり、果樹の種類や環境によっても異なってくるが、その時 の根系がどの様な形状を呈するのか、掘らずに透視調查が行えないものだろうか。外国文 献に、単なる “断根”ではなく“根のせん定”という言葉も見られる昨今、果樹において む、物質生産に有利な根の形を積極的に作り上げる時代が来たと言えるのかむしれない。

\section{3. 理想的根系を考える上でのキーワード}

1) 疎植か密植か：昔の果樹栽培といえば、樹間を充分にとって樹を大きく育て、一樹当 りの収量を上げる疎植大柱義であった。そこには、整枝せん定をはじめとして、余人の 追随を許さぬ名人芸的な技術が求められたが、企業としての果樹栽培を指向する中で、初 期収量の見込める計画密植について検討が進んだ。同じ台木を使用するにしても、両者の 根形には大きな相違が生ずるが、密植栽培では、隣合った樹の根と根がお互いに避けあっ て生長しようとするアレロパシーがあり、根形にも違いが生している。

2）八ウス栽培と露地栽培：ハウス栽培は、露地栽培の数倍の利潤を上げようとする特 殊な栽培システムであり、これまで以上に果実の品質と收量が求められる。温州ミカンの ハウス栽培では、優良品種を密植し、品贒向上のための根域制限や花芽確保のための地中 冷却などの技術が駆使されているが、もはや出荷時期を早めれば僻る時代は終わり、良果 の安定的多収がポイントとなってきた。高品質果が求められるのは蕗地栽培においても同 
様で、根域制限、マルチ、群状結実により実効が上げられつつある。高齢化した農家の作 業軽減をはかるためには、低樹高化が強く望まれるところであり、超わい性のヒリュウを 台木として利用すべく検討が行われているが、根の形や機能に関心を示す農家は少ない。

3）永年生か数年生か？：消費者の二ーズに応え、優良品種への更新を終始念頭におか ざるをえない現況では、果樹を永年生というょりも数年生とみなす方向にあるといってよ い。とくにハウス栽培では、果樹を移動可能なポット植えとし、盛果期を過ぎればこれを あらかじめ用意しておいた別の優良品種のポット植え若木に置き換え、当年にも結実出荷 する企業戦略がとられている。したがって果樹の根についても数年勝負という視点が必要 ということになる。

4 ）収量か品質か？：高品質果の連年多収が果樹栽培の原点であることに変わりはないが、 露地植えの温州ミカンでは土墥表層の細根をできるだけ多くし、群状結実による高品質果 の生産を指向する中で、面積さえあれば隔年結果も肯定される方向にある。又、いわゆる 根域制限栽培では T R 率は低くなるが、これは細根が多くなることによるもので、品質向 上にはプラスに作用しても收量増加には必ずしも結びつかない側面がある。 T R 率は、収 量と品質を論議する上で重要なメルクマールたりうるが、旧来の T R 率ではなく地上部、 地下部の新生部の量と機能に焦点を合わせた新しい T R 率といった考え方が必要であろう。

\section{4. 根系の形作りから機能アップまで}

前回のシンポで論じた点と今回 1 〜 3 で論した点をあわせて考えると、果樹においても 根系の形作りにはじまって役割分担、機能アップを指向することが、「果樹における理想 的根系作り」につながるものと考えられる。ここでは私どもが行った実験の結果より問題 を提起したい。

1) 左右根の補完作用：温州ミカン苗木の根系を左右 2 群に分けて不織布ポットに植え、 左群を施肥、右群を無施肥として樹体生長を調查したところ、施肥側の細根の量は多く、 新梢も多く発生して、その生長も優れた。ただ、無機成分含有率に関しては、無施肥側も 施肥侧と同程度の值を示した。

2) 浅根、深根の機能解析：不織布を用いて、（A）浅根主体、（B）深根主体、 （C）浅根十染根の 3 区を設け、温州ミカン若木の樹体生長を比較したところ、萧枝、細 根の生長量は、（C）、（A）、（B）の順に多く、表層の細根量の少ない深根区の生長 が劣った。

3 ) 根系へのホルモン施用：高畧に不織布ポットを埋め込み、表層の細根はポット上部 の㑼内へ自由に伸長できるが、直根は土中梁くへ伸長できない方式を採用した。このよ5 な温州ミカン若木を材料として、初秋にベンジルアデニン水溶液、プロリン水溶液を株元 に潅注した。その結果、両処理区とも細根の量が増加し、光合成速度も大となり、枝中へ の炭水化物の蓄積も増加して、花らいの着生が優れた。

1) の実験は、高品質果の収䅼を狙った部分群状結実法との関連で実施したもので、枝と 根との対応関係を明かにし、なり枝、不なり枝（予備枝）と対応関係にある根に、それぞ れそれにふさわしい管理を行なえば、高品質果の連年生産にプラスに作用することが推察 された。2）の実験は、理想的な根形作りに関した実験で、土中梁くへの直根の伸長は抑 え、畧の表層部分に細根を多く発生させる方式が、低樹高化も可能とし、種々の根域制限 栽培の中でより現実的であることを示唆しており、3）はそのような方式の根系を介して ホルモンやアミノ酸を添加すれば、花芽を容易に確保できる可能性を示している。

「果樹における理想的根系」に関する議論は、その緒についたばかりである。 


\section{草本植物における最適な地下部／地上部比 \\ : 生態学の立場から}

可知直毅

\section{植物の生理生態学と最適化モテル}

生理生態学は、生物の生理的な営みを解析することによって自然界における生態現象を 理解しようとする学問分野です。伝統的な植物の生理生態学では、光合成や窒素やリンな どの無機栄養の吸収同化といった生理機能がどのように植物個体の生長や植物群落の物質 生産にむすびつくかというメカニズムの研究が中心でした。一方、近年発展のめざましい 進化生態学の影響を受けて、これらの生理的特性を自然選択の結果として理解しようとす る試みもさかんになってきました。生理的な現象（たとえば盖分吸収）にみられる法則性 に基づいて、より高次の現象（たとえば植物個体の成長）をモデル化することによって、

最適な（たとえば成長を最大にする）生理的特性を予測することをめざす最適化モデルは、 こうした研究の有用な手法となっています。

\section{植物の生長モテルと窒素栄養}

植物が成長するためには、地上部の光合成器官が炭酸ガスを有機炭素に固定すると同時 に根系が水と養分を吸收しなければなりません。植物の成長は、異なる機能を担ったこれ らの器官の連係による再生産システムとしてとらえることができます。植物の地上部と地 下部の割合は、生育条件によって変化します。例えば、栄美条件を変えて植物を育てると、 地上部／地下部比は栄美条件が悪いほど小さくなります。負栄美な環境では植物の生理活 性を支えるのに必要な荃分を吸収するためにより多くの根を張らなければならないはずで す。したがって、地上部と地下部の機能のバランスを保つという意味で上記の反応は適応 的と言えます。そこで、ここでは栄差として窒素を取り上げ、ある与えられた窒素条件の もとで、植物個体の成長速度を最大にする地上部/地下部比はどのように決まるかという 問題を最適化モデルを使って考えてみることにします。

\section{モテルの構造}

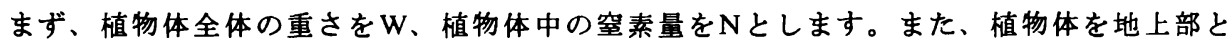
地下部に分けそれぞれの重さをWs、Wrとし、それぞれの窒素量をNs、Nrとします。 さて、植物の乾物成長速度（dW/dt）は、地上部の乾物成長活性 $(\mathrm{SSA}=1 / \mathrm{Ws} \mathrm{dW} / \mathrm{dt})$ と 地上部の重さ（Ws）に分割することができます。

$$
\mathrm{dW} / \mathrm{dt}=1 / \mathrm{Ws} \mathrm{dW} / \mathrm{dt} \times \mathrm{Ws}
$$

同様に、植物の窒素吸収速度（ $\mathrm{dN} / \mathrm{dt} ）$ は、地下部の吸収活性（SRA $=1 / \mathrm{Wr} \mathrm{dN} / \mathrm{dt} ）$ と地 下部の重さ（Wr）に分けられます。 


$$
\mathrm{dN} / \mathrm{dt}=1 / \mathrm{WrdN} / \mathrm{dt} \times \mathrm{Wr}
$$

ここで、地上部と地下部の連係を規定するために以下の二つの関係を仮定します。まず、 地上部の乾物成長活性（SSA）は、地上部の窒素濃度（Cs $=\mathrm{Ns} / \mathrm{Ws})$ によって決るとし ます。これは、葉の窒素濃度と光合成活性との間には高い相関があることが根趣になって います。普通、SSAは地上部の窒素濃度の增加とともに高まりますが、ある窒素濃度

$\left(\mathrm{Cs}{ }^{*}\right)$ 以上では窒素濃度以外の要因が律速になるため頭打ちになります。そこで、ここで は簡単にするため次のような関係を仮定します。すなわち、

$$
\begin{aligned}
& \mathrm{SSA}=\mathrm{a} C \mathrm{Cs}\left(0<\mathrm{Cs} \leqq \mathrm{Cs}^{*}\right) \\
& \mathrm{SSA}=\mathrm{Cs}^{*} \quad\left(\mathrm{Cs} \geqq \mathrm{Cs}^{*}\right)
\end{aligned}
$$

次に、地上部の窒素濃度（Cs）と地下部の窒素濃度（Cr）との閒には正の直線関係があ ると仮定します。

$$
\mathrm{Cr}=\mathrm{bCs}+\mathrm{c}
$$

この仮定を賑付けるような生理機構はいまだ明らかになっていませんが、こうした関倸は 栄美生長をしている植物に一般的にみられるものだと思います。

もしこれらの関係を示すパラメータ（a，b,c，Cs*）が決まりますと、与えられた地下部 の吸収活性（SRA、すなわち窒素栄美条件）のもとで、ある地上部／地下部比を持つ植物 の相対生長速度（RGR）が計算できます。これで、ごく自然な二つの仮定から出発して、 植物の成長速度を最大にする最適な地上部/地下部比が理論的に予測できることがわかり ました。

\section{モテルの広用}

それでは、実際に植物は栄養条件に反応してその地上部／地下部比を最適になるように 調節しているでしょうか。そこで、いろいろな涨度の水耕波で植物を育て成長解析をした 結果を上記のモデルに当てはめてみました。材料にはイギリスの石灰岩質草地に自生し牧 草としても使われるイネ科の植物、シラゲガヤ（Holcus lanatus L.）を用いました。 水耕実験の結果からパラメータの值を推 定してモデル計算をしたところ、次の様な興味 深い結果を得ました。すなわち、「䨘栄美な環境では、植物はその窒素濃度を維持するよ りはむしろ地上部と地下部の比を一定に保つ方が成長速度を最大にできる」という予測で す。このような最適化モデルにより、植物の窒素濃度が筫栄美な環境で低下するという経 検的にはごく当たり前の傾向を、RGR最大化に 対する選択の結果として理解することも可 能と思われます。また、「筫栄養な環境に生育している種は、富栄養な環境に生育してい る種に比べて地上部/地下部比を一定に保つ傾向がある」という経験的な事実も生態学的 な観点から理解することができます。 


\section{理想的根系と土壤 河野恭廣}

\section{空間としての土壤}

土烄は生成時から、不均質な属性をもつ空間的な構造体である。その空間を構成する気相、 液相、固相は動的な関倸にあり、液相の水が失われれば、気相が増加し、風化、収維や有 機物の減耗などによって固相も変化する。これらの過程には植物根系、土壤動物や土㙥微 生物活動などが関わるとともに、逆に変化した空間の状態はそれらの活動を規制する。こ の変化は土埕の深度によっても異なる。この様な土境空間の性質は、生物活動に対して様々 な環境を提供する。また、その性質は大気や水空閒の性質に対比して、光がない暗黒の空 間であることともに、変化の時間においても尺度が異なる。それは空間の不均質性が、自 然の作用によって均質化していく時閒を考えても容易に理解できる。この様な点から、土 境空間における生物の活動を、比較的均質で抵抗の少ない大気や水空間の生物活動と同し 次元で理解するのは困難であり、パラダイムの転換が必要であると考える。理想的根系を 考える上でも、一つの重要な視点ではなかろうか。

\section{根系構造と根系形質}

これまでの一連の研究で、われわれは、イネ科作物が乾燥条件 (pF3.0)から湛水条件まで の土境水分域で、乾物生産能力の低下はあっても、いずれの種も種子を生産しうることを 認めている。

幼植物期から出穂期までの様々な発育段階でえられた、夏作及び冬作イネ科作物 15 種の 全測定值183点を用いて、地上部乾物重 $(S)$ と根系乾物重 $(R)$ の間の単相関を調べた。その結 果、実験年度、ポットの大きさ、種・品種・系統、土境水分（乾燥・適湿・湛水）などの 量いがあっても、回帰式と相関係数は、 $\mathrm{S}=3.616 \mathrm{R}+0.662(\mathrm{r}=0.862 * * *)$ と極めて高い 正の相関が認められた。

この結果は、地球の寒冷化と乾燥化とともに進化してきたイネ科植物種が広籁な土袞水 分域で、ライフサイクルを全うするために、地上部と根系間の乾物分配を調律する能力を 共有することを物語るものであろう。そして、この結果は、根重を対象形賢として種間・ 品種閒差異を見いだすのは困難であり、むしろ実際の各種水分域での生育の良否の原因を、 根系へ分配される乾物利用の仕方の差異に求める方が、有効であることを暗示しているよ うに思われる。

全根系の長さや表面積の約 $90 \%$ を占める㑡根と、それらを土墥空間に配置する「場」と して、そして地上部と側根との間の美水分の供給経路としての節根軸とを区別する必要が ある。全根系重の面からみて、側根は約 $20 \%$ を占めるに過ぎないと推定される（郭・河野 1993）。この様な乾物の長さへの転形効率の高い側根の発達の良否が、理想的根系を考え る上での一つの鍵を握っていると考える。

イネ科作物の側根には $\mathrm{L}$ 型と $\mathrm{S}$ 型の二つの型の側根がある。前者は太く、長く、高次の 側根を発達させ、長さの変異も大きい。後者は短く: 細く、高次の分枝は行なわず、比較 的均一の長さである。これまでのわれわれの研究室での実験結果では、イネ科作物のどの 種でも、L 型側根は乾畋ストレスで増加する。そのような条件下では節根数が減少するか ら、節根に対する保值的な性格の側根と考えている。事実、種子根一本だけで育てたハト ムギでは対照区に比べて L 型側根が約7倍と增加する。一方、S 型は短く、分枝はしないが、 全㑡根数や全根長で、それぞれイネで $94 \%$ と $75 \%$ 、トウモロコシで $93 \%$ と $60 \%$ を占め、根 系の機能を評価する上で大切な器官である。殆ど S 型で占められるイネ種子根系の窒素の 推移からみると、S 型は莱的性格を、節根軸は胚乳的性格をもっているのは大変興味深い。

一方、㑡根を土埣空間に配置する節根の伸長速度は、乾燥からの逃避という面から重要 である。また、側根の発生の「場」としての節根の走向角は、根系の枠組みを決定する上 で重要な形質であるが、土㭛環境の影響を受けやすい上に、種間差異も大きく、理想的根 系的根系を考える際のもう一つの鍵を握っていると考えられよう。 


\section{作物の根系の可塑性}


においても、作物の収量は、改良された作物の遺伝的形質と太陽輻射エネルギーの組合せ によって期待されるほどの高収量が得られないばあいが多い。それは多くの場合、すぐれ て土境に由来するストレスが原因している。作物は、そのストレスを先ず最初に受ける根 系を様々に変化させ成長を図る。したがって、収量や品質を生産目的とする作物における 理想的根系とは、根系に配分されるより少ない光合成産物を効率よく利用して、あらゆる ストレスに対して安定した個体成長を保障する柔軟性を具備した根系と規定できる。

土墥環境に応答して作物が根系の発達状態を変化させ、ライフサイクルを全うする能力 を、O'Toole \& Bland（1987）は「表現型の可塑性」（phenotypic plasticity）と呼び、 「一つの連伝子型が自然環境に反応して異なる表現型を示しうる能力」と定義し、ストレ ス環境における収量の安定性との関連から注目した。

彼らの総説では、イネ科作物と双子葉植物に関するものが取り上げられており、それら の中で取り扱われている形質は根重が最も多く、次に根長、地上部と根重の比、根面積、 根の太さ、根数、根の伸長速度などとなっている。これらの根系の「表現型の可塑性」評 価に関する研究は、究極的に育種的利用を目指したものである。しかし、多くのばあい固 場条件下では、複雑な外部環境要因が品種間差異を覆い隠すために、あまり成功していな い（Russel 1977）。その原因は形質間の可塑性の程度の違いに対するデータの蓄積が足ら ないことに起因するように考える。

\section{土袞空間の管理技術と理想的根系}

農業は、土地（土窑）と労働力と技術によって営まれる。「文明の進歩とともに、人間 は多くの技能を身につけたが、己の食糧の重要な趑りどころである土﨏を保全することを 習得した者は希であった」とするV.カーター（1975）の指摘は、われわれにもう一つの理 想的根系を考える必要性を提起しているように思われる。根系は、土埪空間の生物活動の 一員として、土墥生成の過程で重要な歴史的役割を担ってきたし、現在でもそうであるは ずである。

コムギやイネで計測された結果からみて、一作後 10アール当り乾物にして約 $150 〜 200 \mathrm{~kg}$ 近 い根系を土㙵空間に残す。この残渣は土浐生物の食物連鎖網に入り、また張り巡らされた 根系は粗孔隙として土境構造の形成に関与し、後作の作物根の成長や水の移動にも影響す る。深根性で、硬盤層を貫通しうる根系は、深層への有機物供給者として、そして土識構 造形成者としての役割を果たすのみならず、流亡した無機美分を再び生物界に取り入れる 役割を演ずることにもなる。そして結果として、土㙵空間の拡大に奇与するであろう。

土培微生物と根系との関係は、Hiltner（1904）以来、幾多の蓄積がなされてきたが、土 㙵動物と根系との関係は根食性のものや、土境耕うん作用との関係に限られているように 思われる。土境動物群は、単に腐食性や肉食性のものばかりでなく、菌食性のものもあり、 微生物を介して根系活動に影㗽を及ぼしているはずである。このように、根系一土境微生 物一土境動物は、相互に影響しあって、土坮空閒の安定した生態系を形作り、病原性・植 食性の土頚微生物・動物の侵入や異常增殖を制御している点に再度注意を払う必要がある 亏。地球上での土袞生成の歴史的過程を振り返り、農耕地の土境空間の生産力向上と、そ の永続性をも視野に入れた理想的根系も考えられる時期にあるのではなかろうか。

\section{おわりに}

「米作日本一表彰事業」の技術解析は、深耕・客土・有機物投入と水管理技術の重要性 を導きだした。かって田中（佐賀大）は、多収楼田のイネの根系を見て、「絹糸のような 白い細い根の発達」に注目し、さわった感触を「あたかもきざみタバコを握ったようであ る」と記述している。この叙情的記述は、理想的根系と土裹を考える上できわめて示唆に 富んだものであり、若かった頃の筆者の頭に強く刻み込まれている。 
第 2 回 J S R R シンポジウムに参加して

分析センター・技街研究所土肥哲哉

本会ならびに佐賀大学海浜台地生物生産研究センター、佐賀大学 農学部主催による第 2 回 J S R R シンポジウムが1994年 5月 21,22 日の 2 日間、唐津市の後援を得て、佐賀県唐津市近代図晴館におい て開催されました。シンポジゥムの詳しい内容については、名古屋 大学農学部の山内氏ならびに講演要旨集に境こととします。

今回のシンポジゥムに参加した筆者の個人的感想としては、シン ポジウム最終時の総合討議において、理想的植物根系を把握する上 での問題点として(1)地上部と地下部のコミュニケーション(2)根長・ 根重以外の新たな指標の提案 (3) 1 次根、2 次根等の機能的分類(4)根 系の構造的機能と遺伝・生理的機能の相互関係などが指摘され、根 を研究する者にとって誰もが一度は疑問を感じた点であり、本会合 でこれらが問題提起されたことは画期的であったと思います。現段 階では残念ながらいずれの問題も解決されてはいませんが決して悲 観的になる事もないと思っています。今後は作物、林学、園芸、生 態、土壤、微生物、農業工学、分析化学など根の研究に関する様々 な研究分野において、これらの共通の問題点を認識し、いろいろな 側面から幅広く議論を重ねることによって問題点を少しずつ克服出 来るものと信じております。

また、今回のシンポジウムが唐津市の協力を得たことは、一般の 人々にも根について関心をもって貪う良い機会だったのではないか と思います。

最後に、想親会では唐津の豪華な海の幸、山の幸をサカナに全国 から集まった根の研究者と上下、年令差など関係無く自由に議論が できた事は筆者にとって有意義な 2 日間であり、今回のシンポジウ ムを運営されたスタッフの方々に感謝の意を表します。 